\title{
Adaptation and Content Validity of the Phonological Awareness Test for Mozambique
}

\author{
Gérson O. E. Muitana' and Cibelle A. de la H. Amato² \\ 1 Department of Psychology, Eduardo Mondlane University (UEM) \\ ${ }^{2}$ Center for Biological and Health Sciences, Mackenzie Presbyterian University (UPM)
}

Received: September $15^{\text {th }}, 2020$.

Accepted: May $17^{\text {th }}, 2021$.

\section{Author Note}

Gérson O. E. Muitana (D) https://orcid.org/0000-0002-0724-6607

Cibelle A. de la H. Amato (D) https://orcid.org/00oo-0003-2422-6998

Source of Funding: Academic Excellence Program - Programa de Excelência Acadêmica - PROEX (1133/2019).

Correspondence concerning this article should be addressed to Cibelle Albuquerque de la Higuera Amato, Programa de Pós-Graduação em Distúrbios do Desenvolvimento, Centro de Ciências Biológicas e da Saúde, Universidade Presbiteriana Mackenzie (UPM), Rua da Consolação, 930, Prédio 28, $1^{\circ}$ andar, São Paulo, SP, Brazil. CEP 01302-907.E-mail: cibelle.amato@mackenzie.br 


\begin{abstract}
Phonological awareness is an essential skill for reading, writing, and mathematics performance. Therefore, it is suggested that it be monitored and evaluated preferably during preschool as a form of early intervention to prevent learning difficulties after formal education. However, it is necessary to have qualified instruments for its evaluation and, in Mozambique, none assesses this skill. Therefore, this study aimed to culturally adapt the Phonological Awareness Test by Oral production (PATOP) to the Mozambican context and was conducted in two phases: semantic equivalence and content validation. The Content Validity Index (CVI) was 0.96; although it is considered excellent, further studies need to be carried out to verify other validity, reliability, and standardization parameters. Nevertheless, it is expected that the instrument contributes to the evaluation of phonological awareness and that, above all, the skill is part of activities of stimulation and intervention in preschoolers.
\end{abstract}

Keywords: cultural adaptation, content validity, phonological awareness, Mozambique, evaluation

\title{
ADAPTAÇÃO E VALIDADE DE CONTEÚDO DA PROVA DE CONSCIÊNCIA FONOLÓGICA PARA MOÇAMBIQUE
}

\begin{abstract}
Resumo
A consciência fonológica é uma habilidade muito importante para o desempenho em leitura, escrita e matemática. Sugere-se que seja monitorada e avaliada preferencialmente durante a pré-escola como forma de intervenção precoce para prevenção de dificuldades de aprendizagem após o ensino formal. Contudo, para sua avaliação é necessário ter instrumentos qualificados, e, em Moçambique, não existe nenhum que avalie essa habilidade. Portanto, este estudo teve o objetivo de adaptar culturalmente a Prova de Consciência Fonológica por produção Oral para o contexto moçambicano, o que foi realizado em duas fases: equivalência semântica e validação de conteúdo. O Índice de Validade de Conteúdo foi de 0,96; embora seja considerado ótimo, estudos posteriores precisam ser realizados para verificar outros parâmetros de validade, fidedignidade e normatização. Espera-se que o instrumento contribua para avaliação da consciência fonológica e que, acima de tudo, a habilidade faça parte das atividades de estimulação e intervenção em pré-escolares.

Palavras-chave: adaptação cultural, validade de conteúdo, consciência fonológica, Moçambique, avaliação
\end{abstract}

\section{ADAPTACIÓN Y VALIDEZ DE CONTENIDO DE PRUEBA DE CONCIENCIA FONOLÓGICA PARA MOZAMBIQUE}

\section{Resumen}

La conciencia fonológica es una habilidad muy importante para el desempeño en lectura, escritura y matemáticas, lo que sugiere que se monitorea y evalúa preferiblemente en preescolar como una forma de intervención temprana para prevenir dificultades de aprendizaje en la educación formal. Sin embargo, para su evaluación es necesario contar con instrumentos calificados y en Mozambique no hay 
ninguno que evalúe esta habilidad. Por lo tanto, este estudio tuvo como objetivo adaptar culturalmente el Test de Conciencia Fonológica por producción Oral para Mozambique y se llevó a cabo en dos fases: equivalencia semántica y validación de contenido. El Índice de Validez de Contenido fue de 0,96, aunque se considera excelente, es necesario realizar más estudios para verificar otros parámetros de validez, confiabilidad y estandarización. Se espera que el instrumento contribuya a la evaluación de la conciencia fonológica y que sobre todo, la habilidad sea parte de las actividades de estimulación e intervención en preescolares.

Palabras clave: adaptación cultural, validez de contenido, conciencia fonológica, Mozambique, evaluación 
Phonological Awareness (PA) is a skill that allows us to reflect on the sound segments of what we speak. The spoken language can be segmented into small units, the phrase in words, the words in syllables, and the syllables in phonemes. Therefore, it detects and manipulates sounds, syllables, and words, while its subset (Ciesielski \& Creaghead, 2020). It develops during preschool and early school years, progressing in different linguistic units: from word and syllables awareness to intrasyllabic units awareness - such as onset and rhyme -, and, finally, phoneme awareness (Goswami \& Bryant, 1990).

PA is essential for academic performance and is described by The National Early Literacy Panel (NELP) as one of the six children's skills and competencies that best predict later performance in reading and writing (Shanahan \& Lonigan, 2010). In addition, studies show that this awareness correlates significantly with reading accuracy and fluency and can be predicted in students from the $1^{\text {st }}$ to the $3^{\text {rd }}$ grade of elementary school (Song et al., 2015; Vibulpatanavong \& Evans, 2019). In dyslexic children, PA is the skill with the most significant deficit since the preschool and school periods (Snowling \& Melby-Lervåg, 2016). Other results have shown a positive and significant correlation between PA and writing (Santos et al., 2017), and with the arithmetic competence in the $1^{\text {st }}$-grade children, anticipating mathematical performance in elementary school children (Pazeto et al., 2019; Pinto et al., 2016).

Beyond the correlations presented, PA intervention and stimulation programs have demonstrated their effectiveness in promoting benefits for the performance of writing and reading comprehension in dyslexic children (Germano et al., 2013; Pape-Neumann et al., 2015). Furthermore, they have shown long-term gains in reading for kindergarten children (Diamanti et al., 2017), as well as benefits in reading, decoding, and understanding words in children considered at risk and atypical (Fälth et al., 2017; Kjeldsen et al., 2019).

Because of its importance for academic performance, one of the interventions and early prevention strategies, besides stimulation of ability, has been to evaluate children in the early years of literacy to identify those at risk of having difficulties or specific learning disorders in the future. However, in realities such as Mozambique, where there are no evaluation instruments, one of the recommendations has been to make a cultural adaptation, as it is advantageous in terms of costs (of time and financial) and allows international exchanges of scientific research when compared to the development of a new instrument (Hambleton, 2005).

Thus, looking at the Brazilian reality, for example, in which scientific production is more developed concerning Mozambique in this theme, it was possible to map existing instruments in that country, having been verified that the Phonological Awareness Test by Oral Production (PATOP) had excellent psychometric properties, normative data, and consistency in its results. Furthermore, considering the existence of historical, cultural, and language proximity (Morais, 2019), in addition to the fact that the two linguistic varieties share the 
same basic lexicon (Petter, 2008, 2009), these aspects contributed a lot as criteria for reducing steps to obtain the instrument and for the PATOP to be chosen for adaptation.

PATOP is an instrument that assesses ten components of PA involving the manipulation of speech sounds (Capovilla \& Capovilla, 1998). Studies with the instrument have been conducted in the last 14 years (Dias et al., 2013). Capovilla (2006, as cited in Dias et al., 2013) investigated reliability data in a sample of 379 Brazilian children from the $1^{\text {st }}$ to the $4^{\text {th }}$ grade (corresponding to the $1^{\text {st }}$ to the $4^{\text {th }}$ grade in Portugal or the $1^{\text {st }}$ to the $4^{\text {th }}$ class in Mozambique), and the value of Cronbach's alpha was 0.91; Spearman-Brown coefficient was 0.86; and the test-retest method obtained a coefficient of 0.87 , results considered very satisfactory. For internal consistency, Capovilla et al. (2007) found positive and significant correlations, with moderate to high magnitudes, among each of the ten subtests of the test and the total performance of the instrument in children aged from 6 to 15 years. The study revealed that the test presented evidence of validity for evaluating PA in children, specifically from the $1^{\text {st }}$ to the $3^{\text {rd }}$ grade. The test also presents normative data for children from public schools from 3 years of age onwards (Dias et al., 2013) and norms for preschool 1 children to the $2^{\text {nd }}$ grade of private school (Seabra \& Capovilla, 2011).

In general, studies have shown evidence of validity by correlation with other variables using diversified techniques, such as observing changes with development; correlation with other tests, revealing patterns of convergence with related constructs; and correlation with external criteria, such as the school grade (Dias et al., 2013), in addition to studies in children and adolescents with Williams-Beuren syndrome and Down syndrome. This demonstrates that the instrument has adequate psychometric characteristics for evaluating Brazilian children and adolescents from kindergarten to elementary.

Therefore, it is an instrument that will be very important for the Mozambican context in which preschool education, besides being optional, is provided by private or community institutions (Timbane, 2016), a fact that has contributed to a diversification of contents and not systematization of curricula used in daycare centers, kindergartens, and children's centers. In addition, each children's institution is free to create and adapt the materials, bringing experiences from other realities. Therefore, sometimes the production of this material may fall short of what was intended (Francisco, 2015). On the other hand, this tool will be highly fundamental, since some studies have pointed out that Mozambican children have deficits in essential reading and writing skills in the Portuguese language; deficits in recognition of letters of the alphabet; and deficits in counting and calculating skills (Fundação Aga Khan, 2011; TPC Moçambique, 2017). Other studies concluded that one of the causes of the deficits was the inadequate preparation of children and the prerequisites of these children before entering primary school (Nhampossa, 2018; United Nations Educational, Scientific and Cultural Organization [UNESCO], 2007, 2012). In this way, an instrument for PA evaluation can contribute 
for children to be assessed mainly in preschool and be better referred early to prevent possible learning difficulties (LD) in formal education. On the other hand, it will contribute by providing adequate educational opportunities and, consequently, reducing the high rates of inconclusion in primary education, as well as the high school failure rates in that African country (UNESCO, 2007, 2012).

Concerning the process of cultural adaptation of psychological instruments from a given context to another, Fonseca et al. (2011) refer that it is not just about translation (because language and culture interfere in the evaluation process as a whole). Therefore, it is emphasized that the adaptation follows specific procedures, steps, and techniques and obeys a certain methodological rigor. One of the first steps in this process is searching for evidence of content validity that seeks to verify that the instrument continues to measure the same construct (Pasquali, 2013). This search is verified through the experts' analysis and judgment (Pasquali, 2003) and, for that, at least two approaches, generally qualitative and quantitative, can be used. The qualitative one uses semantic, idiomatic, conceptual, and experimental equivalences (Guillemin, 1995). One of the quantitative approaches has been calculating the Content Validity Index (CVI) to quantify the degree of agreement among experts (Coluci et al., 2015).

Therefore, this study aims to carry out the cultural adaptation and content validation of the PATOP for the Mozambican context. It is believed that this instrument will be helpful to the extent that it will be the first in the country. It is expected a significant contribution to neuropsychological evaluation, especially in the screening of academic performance predictors. It is also expected that further studies will be carried out with the instrument and that, in the future, other pieces of evidence of validity and precision will be verified, besides the elaboration of normative data for its use in the clinic and in the scientific research.

\section{Method}

This is a methodological study of the cultural adaptation of an instrument. All methodological procedures and theoretical approaches used were based on scientific research on the subject and the International Test Commission (ITC) guidelines for translation and adaptation (second edition). The study was carried out in two phases: 1 . semantic equivalence carried out by Mozambican natives; 2 . content validation carried out by a committee of judges and experts.

\section{Participants}

In phase 1, ten individuals were initially invited, but nine natives participated in the study. All of them are adults, university students and residents in the city of Sao Paulo for at least an average of two years $(S D=2.2)$, six males and three females, between 26 and 47 years 
old. One of the criteria used for the selection was the signing of the Free and Informed Consent Form (IC), and the other was having lived in Mozambique for at least ten years. In phase 2, six judges were invited, but only four participated, namely: two psychologists specializing in Childhood Development and Education, one master in psychological evaluation and one pedagogue specialized in Child Psychology and Intervention. The selection criteria were: to have at least a Master's degree or preferably specialization in the child psychological evaluation field and have at least five years of practical experience in these fields.

\section{Cultural adaptation process}

For ethical research reasons, firstly, the formal consent of the instrument authors was obtained to authorize the adaptation. Then, the project was approved by the ethics committee of the Mackenzie Presbyterian University, with Certificate of Presentation of Ethical Appreciation (or Certificado de Apresentação para Apreciação Ética, in Portuguese - CAAE) under n. 15548519.4.0000.0084. Finally, all individuals were invited to participate spontaneously by signing the IC.

In phase 1, the instrument was subjected to a balanced analysis of linguistic, cultural, and contextual considerations by the strata of the target population. First, the adequacy of all items of the instrument (words, phrases, and expressions) was evaluated and analyzed using the criteria: good, regular, or very bad. If any item was inadequate or incomprehensible, it was suggested to the natives to present possible suggestions for change, which were later analyzed and altered in the instrument so that the preliminary Mozambican version of PATOP could be elaborated. Then, in phase 2 , the instrument was analyzed by Mozambican judges to validate the content. The experts verified that the adapted version reflected the items "clarity" as proposed by the original version, suggesting changes and recommendations. Then, the final version called "PATOP - Mozambican version" emerged.

\section{Instruments}

\section{Phonological Awareness Test through Oral Production}

Capovilla and Capovilla (1998) developed PATOP, based on the PA test and the Sound Linkage test. The test is guided by the applicator, who gives the instructions orally explaining what needs to be done; after that, the examinee also answers orally, and this is noted. The score ranges from 0 to 40, with each correct answer being worth one point. The application must be made individually, and the average time is 20 minutes. Ten PA components are evaluated by ten subtests, each consisting of four items and two initial examples (Seabra \& Capovilla, 2012). The subtests are: 
1. Syllabic Synthesis: the applicator pronounces the syllables of a word giving a one-second interval between them. The examinee must unite them, saying which word occurs as a result.

2. Phonemic Synthesis: the applicator pronounces the phonemes of a word separately, and the examinee must unite them by saying the word resulting from the union.

3. Rhyme: the applicator pronounces three words, and the examinee must select among them the two that end with the same sound.

4. Alliteration: the applicator presents three words, and the examinee must select the two that start with the same sound.

5. Syllabic segmentation: the applicator pronounces a word, and the examinee must repeat it, separating it into its component syllables.

6. Phonemic Segmentation: the applicator pronounces a word, and the examinee must repeat it in its component phonemes.

7. Syllabic Manipulation: the examinee must add and subtract syllables from words, saying which word is formed, according to the syllable provided by the applicator.

8. Phonemic Manipulation: the examinee must add and subtract phonemes from words, saying which word is formed according to the phonemes provided by the applicator.

9. Syllabic transposition: the applicator says the word, and the examinee must invert the order of the syllables, saying which new word is formed.

10. Phonemic Transposition: the examinee must invert the order of the phonemes of words, saying which new word is formed.

\section{Semantic equivalence questionnaire for natives}

It was developed for this study and it aimed to collect information from natives regarding their perception of terms and expressions from the original test that would not be commonly used in Mozambique. In addition to collecting demographic data, the semantic questionnaire presented a table with all the items of the ten PATOP subtests (task description, instructions, training 1 and 2, and tests 1, 2, 3, and 4) and the two sections (test data and structure /presentation), followed by blanks to mark the evaluation (good, regular, or very bad). If the evaluation was regular or very bad, the natives suggested changes considering the characteristics of the original item.

\section{Questionnaire for judges and experts}

It was developed for this study and created using the Google Forms online platform, inspired by the Coluci et al.'s (2015) model. In the first part, the IC and the researchers' dec- 
laration were presented. In the second, the judges were asked to evaluate the clarity of all the instrument items and an additional item (structure and presentation) based on three criteria: understanding, objectivity, and contextualization (linguistic, semantic, and idiomatic). "Understanding" evaluated the intelligibility of all items of the instrument to the target audience. "Objectivity" assessed the appropriate description of the items for their correct application and scoring by the applicators. "Contextualization" evaluated whether the instrument's words and expressions had language, vocabulary, meanings, and writing commonly used in the target population. At the same time, the structure and presentation evaluated whether the entire instrument and the answer sheet presented an adequate organization, as well form and structure, of the text. Finally, the criteria were evaluated and filled according to a Likert scale ranging from 1 to 4 . In this evaluation, judges were also asked to make changes but to maintain the original instrument's properties.

\section{Data analysis}

In phase 1, all data were analyzed qualitatively, considering the suggestions of phrases and expressions made by the natives. In phase 2 , they were analyzed qualitatively using a Likert scale (1=unclear; 2 =not very clear; 3 =quite clear; and 4 =very clear) (Pasquali, 2010). All items with a score of 1 and 2 and those whose judges suggested changes were considered inadequate. So, they were analyzed and changed in the instrument. Then, the data were analyzed quantitatively, calculating the CVI of the items (task description, instructions, training 1 and 2 , and tests $1,2,3$, and 4 ) of the 10 subtests and the two sections (test data and structure/ presentation of the test). To calculate the CVI of the items according to the proposed criteria, the answers 3 and 4 of the judges were added in the items of each subtest and the result of this sum divided by the total number of answers, according to the formula: CVI=Number of answers 3 or 4 / Total number of responses (Coluci et al., 2015; Grant \& Davis, 1997). The CVI value $>0.80$ was considered acceptable and adequate (Pasquali, 2010; Wynd et al., 2003). To calculate the total CVI of the instrument, all CVI of each criterion of the 10 subtests and the two sections were added, finding their arithmetic means. Subsequently, the arithmetic averages were added and divided by the number of sections evaluated throughout the instrument. All suggestions and comments from the judges were analyzed and the changes were made.

\section{Results}

In phase 1, the natives evaluated the instrument, suggested changes in words and phrases to make them suitable for Portuguese spoken in Mozambique, and then changes were made. Table 1 shows the adaptations made by natives from the original PATOP. 
Table 1

Adaptations made by natives from the original PATOP

\begin{tabular}{|c|c|c|c|c|}
\hline Test & Item & $\begin{array}{l}\text { Word / Expression of } \\
\text { the original PATOP }\end{array}$ & $\mathbf{N}$ & $\begin{array}{l}\text { Carried out } \\
\text { adaptation }\end{array}$ \\
\hline \multirow{3}{*}{ Test Data } & \multirow{3}{*}{$\begin{array}{l}\text { Instructions, } \\
\text { application, scoring }\end{array}$} & Registro & 9 & Registo \\
\hline & & Probando & 8 & Avaliado \\
\hline & & Correta & 9 & Correcta \\
\hline Syllabic Synthesis & Instruction & Está falando & 7 & Está a falar \\
\hline \multirow{4}{*}{ Rime } & \multirow{2}{*}{ Training 2} & Sereia & \multirow{2}{*}{4} & Areia \\
\hline & & Canoa & & Coroa \\
\hline & Training 3 & Rolha & \multirow{2}{*}{6} & Folha \\
\hline & Training 4 & Sopé & & Maré \\
\hline \multirow{3}{*}{ Alliteration } & Training 1 & Fada & 4 & Fama \\
\hline & Test 1 & Boné & 6 & Bota \\
\hline & Training 2 & Bexiga & 6 & Cidade \\
\hline \multirow{2}{*}{$\begin{array}{l}\text { Syllabic } \\
\text { Segmentation }\end{array}$} & Tests 3 & Fazenda & 9 & Machamba \\
\hline & Tests 4 & Gelatina & 4 & Televisão \\
\hline \multirow{2}{*}{$\begin{array}{l}\text { Syllabic } \\
\text { Manipulation }\end{array}$} & \multirow{2}{*}{ Instruction } & Adicionar & \multirow{2}{*}{5} & Acrescentar \\
\hline & & Subtrair & & Tirar \\
\hline
\end{tabular}

Source: Data from the native semantic equivalence questionnaire.

All words replaced in the test were based on the number of syllables that belonged to the original word and not necessarily the semantic group, in order to bring the adapted version closer to the original version. In phase 2, after the evaluation and scoring of the four experts, the CVI of each section of the instrument was calculated according to the three criteria. Table 2 shows the CVI of all sections of the PATOP. All values of the criteria had scores above 0.90 , except the criterion "contextualization" of the section "test data, instructions, application, scoring", which had a score of 0.75 . 
Table 2

Content Validity Index - CVI of all PATOP sections

\begin{tabular}{|c|c|c|c|c|c|c|c|c|c|c|c|c|}
\hline \multicolumn{13}{|c|}{ Test data, instructions for application and scoring } \\
\hline \multirow{2}{*}{ Test items } & \multicolumn{4}{|c|}{ Understanding } & \multicolumn{4}{|c|}{ Objectivity } & \multicolumn{4}{|c|}{ Contextualization } \\
\hline & No & Little & Quite & Much & No & Little & Quite & Much & No & Little & Quite & Much \\
\hline \multirow{2}{*}{$\begin{array}{l}\text { Test data, instructions, } \\
\text { application, scoring } \\
\text { CVI }\end{array}$} & 0 & 0 & 2 & 2 & 0 & 0 & 1 & 3 & o & 1 & 1 & 2 \\
\hline & 1 & & & & 1 & & & & 0.75 & & & \\
\hline \multicolumn{13}{|c|}{ Syllabic Synthesis Subtest } \\
\hline \multirow{2}{*}{ Syllabic Synthesis } & \multicolumn{4}{|c|}{ Understanding } & \multicolumn{4}{|c|}{ Objectivity } & \multicolumn{4}{|c|}{ Contextualization } \\
\hline & No & Little & Quite & Much & No & Little & Quite & Much & No & Little & Quite & Much \\
\hline Description & o & o & 2 & 2 & o & o & 2 & 2 & o & 1 & 1 & 2 \\
\hline Instructions & 0 & 0 & 2 & 2 & 0 & 0 & 3 & 1 & 0 & 0 & 1 & 3 \\
\hline Training 1 & 0 & 0 & 0 & 4 & o & 0 & 0 & 4 & 0 & 0 & 0 & 4 \\
\hline Training 2 & 0 & 0 & 0 & 4 & 0 & 0 & 0 & 4 & 0 & 0 & 0 & 4 \\
\hline Test 1 & 0 & 0 & 0 & 4 & o & 0 & 0 & 4 & 0 & 0 & 2 & 2 \\
\hline Test 2 & 0 & $\mathrm{O}$ & 0 & 4 & 0 & 0 & 0 & 4 & 0 & 0 & 0 & 4 \\
\hline Test 3 & 0 & 0 & 0 & 4 & 0 & 0 & 0 & 4 & 0 & 0 & 1 & 3 \\
\hline Test 4 & 0 & 0 & 0 & 4 & 0 & 0 & 1 & 3 & 0 & 0 & 1 & 3 \\
\hline CVI & 1 & & & & 1 & & & & 0.96 & & & \\
\hline \multicolumn{13}{|c|}{ Phonemic Synthesis Subtest } \\
\hline \multirow{2}{*}{ Phonemic Synthesis } & \multicolumn{4}{|c|}{ Understanding } & \multicolumn{4}{|c|}{ Objectivity } & \multicolumn{4}{|c|}{ Contextualization } \\
\hline & No & Little & Quite & Much & No & Little & Quite & Much & No & Little & Quite & Much \\
\hline Description & $\mathrm{O}$ & 0 & 1 & 3 & o & o & 1 & 3 & 0 & 1 & $\mathrm{O}$ & 3 \\
\hline Instructions & 0 & 0 & 0 & 4 & 0 & $\mathrm{o}$ & 1 & 3 & 0 & 0 & 2 & 2 \\
\hline Training 1 & 0 & 0 & 1 & 3 & 0 & 0 & 0 & 4 & 0 & 0 & 1 & 3 \\
\hline Training 2 & 0 & 0 & 3 & 1 & 0 & 0 & 1 & 3 & 0 & 0 & 1 & 3 \\
\hline Test 1 & 0 & 0 & 0 & 4 & 0 & 0 & 1 & 3 & 0 & 0 & 2 & 2 \\
\hline Test 2 & 0 & 0 & 0 & 4 & 0 & 0 & 2 & 2 & 0 & 0 & 1 & 3 \\
\hline Test 3 & 0 & 0 & 0 & 4 & 0 & 0 & 0 & 4 & 0 & 0 & 1 & 3 \\
\hline Test 4 & 0 & 0 & 1 & 3 & 0 & 1 & 3 & 3 & 0 & 0 & 2 & 2 \\
\hline $\mathrm{CVI}$ & 1 & & & & 0.96 & & & & 0.96 & & & \\
\hline
\end{tabular}




\begin{tabular}{|c|c|c|c|c|c|c|c|c|c|c|c|c|}
\hline \multicolumn{13}{|c|}{ Rhyme subtest } \\
\hline \multirow{2}{*}{ Rhyme } & \multicolumn{4}{|c|}{ Understanding } & \multicolumn{4}{|c|}{ Objectivity } & \multicolumn{4}{|c|}{ Contextualization } \\
\hline & No & Little & Quite & Much & No & Little & Quite & Much & No & Little & Quite & Much \\
\hline Description & 0 & 0 & 0 & 4 & 0 & 0 & 0 & 4 & 0 & 0 & 1 & 3 \\
\hline Instructions & 0 & 0 & 0 & 4 & 0 & 0 & 0 & 4 & $\mathrm{o}$ & 0 & 1 & 3 \\
\hline Training 1 & 0 & 0 & 0 & 4 & 0 & 0 & 0 & 4 & 0 & 0 & 0 & 4 \\
\hline Training 2 & 0 & 0 & 0 & 4 & 0 & 0 & 0 & 4 & $\mathrm{o}$ & 0 & 1 & 3 \\
\hline Test 1 & 0 & 0 & 0 & 4 & 0 & 0 & 0 & 4 & 0 & 0 & 1 & 3 \\
\hline Test 2 & $\mathrm{o}$ & $\mathrm{o}$ & 0 & 4 & 0 & 0 & 0 & 4 & 0 & 0 & 0 & 4 \\
\hline Test 3 & 0 & 0 & 0 & 4 & 0 & 0 & 0 & 4 & 0 & 0 & 1 & 3 \\
\hline Test 4 & 0 & 0 & 0 & 4 & 0 & 1 & 0 & 4 & $\mathrm{o}$ & 0 & 1 & 3 \\
\hline $\mathrm{CVI}$ & 1 & & & & 0.96 & & & & 1 & & & \\
\hline \multicolumn{13}{|c|}{ Alliteration Subtest } \\
\hline \multirow{2}{*}{ Alliteration } & \multicolumn{4}{|c|}{ Understanding } & \multicolumn{4}{|c|}{ Objectivity } & \multicolumn{4}{|c|}{ Contextualization } \\
\hline & No & Little & Quite & Much & No & Little & Quite & Much & No & Little & Quite & Much \\
\hline Description & 0 & 0 & 0 & 4 & 0 & 0 & 1 & 3 & o & 0 & 2 & 2 \\
\hline Instructions & 0 & 0 & 1 & 3 & 0 & 0 & 0 & 4 & $\mathrm{o}$ & 0 & 0 & 4 \\
\hline Training 1 & 0 & 0 & 0 & 4 & 0 & 0 & 0 & 4 & 0 & 1 & 3 & 0 \\
\hline Training 2 & o & o & 1 & 3 & 0 & 0 & 0 & 4 & o & 0 & 1 & 3 \\
\hline Test 1 & 0 & $\mathrm{O}$ & 0 & 4 & 0 & 0 & 0 & 4 & 0 & 0 & o & 4 \\
\hline Test 2 & 0 & 1 & 1 & 2 & 1 & 0 & 0 & 3 & o & 0 & $\mathrm{o}$ & 4 \\
\hline Test 3 & 0 & 0 & 1 & 3 & 0 & 0 & 2 & 2 & 0 & 0 & 1 & 3 \\
\hline Test 4 & 0 & 0 & 0 & 4 & o & o & 1 & 3 & 0 & 0 & 0 & 4 \\
\hline CVI & 0.96 & & & & 0.96 & & & & 0.96 & & & \\
\hline \multicolumn{13}{|c|}{ Syllabic Segmentation Subtest } \\
\hline \multirow{2}{*}{ Syllabic Segmentation } & \multicolumn{4}{|c|}{ Understanding } & \multicolumn{4}{|c|}{ Objectivity } & \multicolumn{4}{|c|}{ Contextualization } \\
\hline & No & Little & Quite & Much & No & Little & Quite & Much & No & Little & Quite & Much \\
\hline Description & $\mathrm{o}$ & 0 & 1 & 3 & 0 & 0 & 2 & 2 & 0 & 0 & 3 & 1 \\
\hline Instructions & 0 & 0 & 2 & 2 & 0 & 0 & 1 & 3 & $\mathrm{o}$ & 1 & 2 & 1 \\
\hline Training 1 & 0 & $\mathrm{O}$ & 0 & 4 & 0 & 0 & 0 & 4 & 0 & 0 & 1 & 3 \\
\hline Training 2 & $\mathrm{o}$ & $\mathrm{o}$ & 1 & 3 & o & 0 & 0 & 4 & $\mathrm{o}$ & 0 & 1 & 3 \\
\hline Test 1 & 0 & 0 & 0 & 4 & 0 & 0 & 0 & 4 & o & 0 & 1 & 3 \\
\hline Test 2 & 0 & 0 & 0 & 4 & 0 & 0 & 0 & 4 & 0 & 0 & 0 & 4 \\
\hline Test 3 & 0 & 0 & 0 & 4 & 0 & 0 & 0 & 4 & o & 0 & 0 & 4 \\
\hline Test 4 & 0 & 0 & 0 & 4 & 0 & 0 & 0 & 4 & 0 & 0 & 0 & 4 \\
\hline CVI & 1 & & & & 1 & & & & 0.96 & & & \\
\hline
\end{tabular}


Phonemic Segmentation Subtest

\begin{tabular}{|c|c|c|c|c|c|c|c|c|c|c|c|c|}
\hline \multirow{2}{*}{ Phonemic Segmentation } & \multicolumn{4}{|c|}{ Understanding } & \multicolumn{4}{|c|}{ Objectivity } & \multicolumn{4}{|c|}{ Contextualization } \\
\hline & No & Little & Quite & Much & No & Little & Quite & Much & No & Little & Quite & Much \\
\hline Description & 0 & 0 & 1 & 3 & 0 & 0 & 1 & 3 & 0 & 0 & 2 & 2 \\
\hline Instructions & 0 & 0 & 2 & 2 & 0 & 1 & 0 & 3 & 0 & 1 & 1 & 2 \\
\hline Training 1 & 0 & 0 & 1 & 3 & 0 & 0 & 2 & 2 & 0 & 0 & 1 & 3 \\
\hline Training 2 & 0 & 0 & 0 & 4 & 0 & 0 & 1 & 3 & 0 & 0 & 0 & 4 \\
\hline Test 1 & $\mathrm{O}$ & $\mathrm{o}$ & $\mathrm{o}$ & 4 & $\mathrm{O}$ & $\mathrm{O}$ & 0 & 4 & $\mathrm{O}$ & 0 & 1 & 3 \\
\hline Test 2 & 0 & 0 & 0 & 4 & 0 & 0 & 0 & 4 & 0 & 0 & 2 & 2 \\
\hline Test 3 & 0 & 0 & 1 & 3 & 0 & 0 & 1 & 3 & 0 & 0 & 1 & 3 \\
\hline Test 4 & 0 & 0 & 0 & 4 & 0 & 0 & o & 4 & 0 & 0 & 0 & 4 \\
\hline $\mathrm{CVI}$ & 1 & & & & 0.96 & & & & 0.96 & & & \\
\hline
\end{tabular}

Syllabic Manipulation Subtest

\begin{tabular}{|c|c|c|c|c|c|c|c|c|c|c|c|c|}
\hline \multirow{2}{*}{ Syllabic Manipulation } & \multicolumn{4}{|c|}{ Understanding } & \multicolumn{4}{|c|}{ Objectivity } & \multicolumn{4}{|c|}{ Contextualization } \\
\hline & No & Little & Quite & Much & No & Little & Quite & Much & No & Little & Quite & Much \\
\hline Description & 0 & 0 & 1 & 3 & 0 & $\mathrm{O}$ & 1 & 3 & 0 & 0 & 1 & 3 \\
\hline Instructions & 0 & 0 & 1 & 3 & $\mathrm{o}$ & 0 & 3 & 1 & $\mathrm{o}$ & 1 & 1 & 2 \\
\hline Training 1 & 0 & $\mathrm{O}$ & 0 & 4 & 0 & 0 & 2 & 2 & 1 & 0 & 1 & 2 \\
\hline Training 2 & $\mathrm{o}$ & $\mathrm{O}$ & 0 & 4 & $\mathrm{o}$ & 0 & 0 & 4 & $\mathrm{o}$ & 0 & 1 & 3 \\
\hline Test 1 & 0 & 0 & 0 & 4 & 0 & 0 & 1 & 3 & 0 & 0 & 1 & 3 \\
\hline Test 2 & 0 & 0 & 1 & 3 & 0 & 0 & 0 & 4 & 0 & 0 & 1 & 3 \\
\hline Test 3 & 0 & $\mathrm{O}$ & 0 & 4 & 0 & 0 & 0 & 4 & 0 & 0 & 0 & 4 \\
\hline Test 4 & $\mathrm{o}$ & $\mathrm{o}$ & 1 & 3 & 0 & 0 & 1 & 3 & $\mathrm{o}$ & $\mathrm{o}$ & 2 & 2 \\
\hline CVI & 1 & & & & 1 & & & & 0.93 & & & \\
\hline
\end{tabular}

Phonemic manipulation subtest

\begin{tabular}{|c|c|c|c|c|c|c|c|c|c|c|c|c|}
\hline \multirow{2}{*}{ Phonemic Manipulation } & \multicolumn{4}{|c|}{ Understanding } & \multicolumn{4}{|c|}{ Objectivity } & \multicolumn{4}{|c|}{ Contextualization } \\
\hline & No & Little & Quite & Much & No & Little & Quite & Much & No & Little & Quite & Much \\
\hline Description & 0 & 0 & 1 & 3 & 0 & 0 & 1 & 3 & 0 & 0 & 3 & 1 \\
\hline Instructions & 0 & 0 & 0 & 4 & $\mathrm{O}$ & 0 & 1 & 3 & $\mathrm{o}$ & 1 & $\mathrm{O}$ & 3 \\
\hline Training 1 & 0 & 0 & 1 & 3 & 0 & 0 & 0 & 4 & 1 & 0 & 1 & 3 \\
\hline Training 2 & $\mathrm{o}$ & 0 & 1 & 3 & 0 & 0 & 0 & 4 & $\mathrm{o}$ & 0 & 1 & 3 \\
\hline Test 1 & 0 & 0 & 0 & 4 & 0 & 0 & 1 & 3 & $\mathrm{o}$ & 0 & 1 & 3 \\
\hline Test 2 & $\mathrm{o}$ & $\mathrm{o}$ & 0 & 4 & 0 & 0 & 0 & 4 & $\mathrm{o}$ & 0 & 1 & 3 \\
\hline Test 3 & $\mathrm{o}$ & 0 & 0 & 4 & 0 & 0 & 1 & 3 & 0 & 1 & 1 & 2 \\
\hline Test 4 & 0 & 0 & 0 & 4 & 0 & 0 & 1 & 3 & 0 & 0 & 0 & 4 \\
\hline $\mathrm{CVI}$ & 1 & & & & 1 & & & & 0.90 & & & \\
\hline
\end{tabular}


Syllable Transposition Subtest

\begin{tabular}{|c|c|c|c|c|c|c|c|c|c|c|c|c|}
\hline \multirow{2}{*}{ Syllabic Transposition } & \multicolumn{4}{|c|}{ Understanding } & \multicolumn{4}{|c|}{ Objectivity } & \multicolumn{4}{|c|}{ Contextualization } \\
\hline & No & Little & Quite & Much & No & Little & Quite & Much & No & Little & Quite & Much \\
\hline Description & 0 & 0 & 0 & 4 & 0 & 0 & 0 & 4 & 0 & 0 & 3 & 1 \\
\hline Instructions & $\mathrm{O}$ & $\mathrm{O}$ & $\mathrm{O}$ & 4 & $\mathrm{O}$ & 1 & 1 & 2 & $\mathrm{O}$ & 1 & 1 & 2 \\
\hline Training 1 & $\mathrm{O}$ & $\mathrm{O}$ & 1 & 3 & $\mathrm{O}$ & 0 & 1 & 3 & 1 & $\mathrm{O}$ & 2 & 2 \\
\hline Training 2 & 0 & $\mathrm{O}$ & $\mathrm{O}$ & 4 & $\mathrm{O}$ & $\mathrm{O}$ & $\mathrm{O}$ & 4 & 0 & $\mathrm{O}$ & 2 & 2 \\
\hline Test 1 & 0 & 0 & 0 & 4 & 0 & 0 & 1 & 3 & 0 & 0 & 1 & 3 \\
\hline Test 2 & 0 & 0 & 0 & 4 & 0 & 0 & 0 & 4 & 0 & 0 & 0 & 4 \\
\hline Test 3 & 0 & 0 & 0 & 4 & 0 & 0 & 1 & 3 & 0 & 0 & 0 & 4 \\
\hline Test 4 & 1 & O & o & 3 & 1 & o & 1 & 2 & 1 & o & 0 & 3 \\
\hline CVI & 0.96 & & & & 0.93 & & & & 0.90 & & & \\
\hline
\end{tabular}

Phonemic Transposition Subtest

\begin{tabular}{|c|c|c|c|c|c|c|c|c|c|c|c|c|}
\hline \multirow{2}{*}{ Phonemic Transposition } & \multicolumn{4}{|c|}{ Understanding } & \multicolumn{4}{|c|}{ Objectivity } & \multicolumn{4}{|c|}{ Contextualization } \\
\hline & No & Little & Quite & Much & No & Little & Quite & Much & No & Little & Quite & Much \\
\hline Description & 0 & 0 & 3 & 1 & 0 & $\mathrm{O}$ & 1 & 3 & 0 & 0 & 2 & 2 \\
\hline Instructions & 0 & $\mathrm{o}$ & 0 & 4 & 0 & 1 & 2 & 2 & $\mathrm{o}$ & 1 & 1 & 2 \\
\hline Training 1 & 0 & $\mathrm{O}$ & 1 & 3 & 0 & 0 & 1 & 3 & 1 & 0 & 1 & 3 \\
\hline Training 2 & $\mathrm{o}$ & $\mathrm{O}$ & $\mathrm{o}$ & 4 & 0 & 0 & 0 & 4 & $\mathrm{o}$ & 0 & 1 & 3 \\
\hline Test 1 & 1 & 0 & 0 & 3 & 1 & 0 & 0 & 3 & 0 & 0 & 1 & 3 \\
\hline Test 2 & 0 & 0 & 1 & 3 & 0 & 0 & 0 & 4 & 0 & 0 & 0 & 4 \\
\hline Test 3 & 0 & $\mathrm{O}$ & 0 & 4 & 0 & 0 & 0 & 4 & 0 & 0 & 0 & 4 \\
\hline Test 4 & $\mathrm{o}$ & $\mathrm{o}$ & 2 & 2 & 0 & 0 & 2 & 2 & $\mathrm{o}$ & 0 & 3 & 1 \\
\hline $\mathrm{CVI}$ & 0.96 & & & & 0.93 & & & & 0.93 & & & \\
\hline
\end{tabular}

Structure and Presentation

\begin{tabular}{|c|c|c|c|c|c|c|c|c|c|c|c|c|}
\hline \multirow{2}{*}{ Additional Item } & \multicolumn{4}{|c|}{ Understanding } & \multicolumn{4}{|c|}{ Objectivity } & \multicolumn{4}{|c|}{ Contextualization } \\
\hline & No & Little & Quite & Much & No & Little & Quite & Much & No & Little & Quite & Much \\
\hline Structure and Presentation & $\mathrm{O}$ & o & $\mathrm{O}$ & 4 & 0 & 0 & 1 & 3 & 0 & $\mathrm{O}$ & $\mathrm{O}$ & 4 \\
\hline CVI & 1 & & & & 1 & & & & 1 & & & \\
\hline
\end{tabular}

Source: Judges and experts' questionnaire. 
Table 3 shows the total CVI of the adapted PATOP. Thus, it can be verified that the value of the arithmetic means of each section ranged from 0.91 (test data, instructions, application, scoring) to 1 (structure and presentation).

\section{Table 3}

Total CVI of the adapted PATOP

\begin{tabular}{lllll}
\hline CVI of the test of sections & Understanding & Objectivity & Contextualization & Average \\
\hline CVI Test Data & 1 & 1 & 0.75 & 0.91 \\
CVI Syllabic Synthesis & 1 & 1 & 0.96 & 0.98 \\
CVI Phonemic Synthesis & 1 & 0.96 & 0.96 & 0.97 \\
CVI Rhyme & 1 & 0.96 & 1 & 0.98 \\
CVI Alliteration & 0.96 & 0.96 & 0.96 & 0.96 \\
CVI Syllabic Segmentation & 1 & 1 & 0.96 & 0.98 \\
CVI Phonemic Segmentation & 1 & 0.96 & 0.96 & 0.97 \\
CVI Syllabic Manipulation & 1 & 1 & 0.93 & 0.97 \\
CVI Phonemic Manipulation & 1 & 1 & 0.90 & 0.96 \\
CVI Syllabic Transposition & 0.96 & 0.93 & 0.90 & 0.93 \\
CVI Phonemic Transposition & 0.96 & 0.93 & 0.93 & 0.94 \\
CVI Structure and Presentation & 1 & 1 & 1 & 1 \\
TOTAL CVI & $\mathbf{0 . 9 9}$ & $\mathbf{0 . 9 7}$ & $\mathbf{0 . 9 3}$ & $\mathbf{0 . 9 6}$ \\
\hline
\end{tabular}

Source: Judges and experts' questionnaire.

In addition, the judges also suggested changes to the instrument and Table 4 shows the adaptations they made to the preliminary PATOP.

\section{Table 4}

Adaptations made by judges in the preliminary PATOP

\begin{tabular}{|c|c|c|c|c|}
\hline Test & Item & $\begin{array}{l}\text { Original PATOP } \\
\text { word/expression }\end{array}$ & Judges & Carried out adaptation \\
\hline Test Data & Test data & $\begin{array}{l}\text { "... Pontuação } 1 / 2 \text { pode ser } \\
\text { atribuída em casos..." }\end{array}$ & 3 & $\begin{array}{l}\text { "... Metade da pontuação } \\
\text { (o.5) pode ser atribuída } \\
\text { nos casos..." }\end{array}$ \\
\hline \multirow[t]{2}{*}{$\begin{array}{l}\text { Syllabic and } \\
\text { Phonemic Synthesis }\end{array}$} & Description & $\begin{array}{l}\text { "... dizendo qual palavra } \\
\text { resulta da união." }\end{array}$ & 2 & $\begin{array}{l}\text { "... e dizer qual é a } \\
\text { palavra que resulta } \\
\text { dessa união." }\end{array}$ \\
\hline & Instruction & $\begin{array}{l}\text { "... e você deve } \\
\text { adivinhar..." }\end{array}$ & 2 & $\begin{array}{l}\text { "... e a sua tarefa é de } \\
\text { adivinhar..." }\end{array}$ \\
\hline
\end{tabular}




\begin{tabular}{|c|c|c|c|c|}
\hline Test & Item & $\begin{array}{l}\text { Original PATOP } \\
\text { word/expression }\end{array}$ & Judges & Carried out adaptation \\
\hline Phonemic Synthesis & Training 2 & Laço & 1 & Pato \\
\hline \multirow[t]{3}{*}{ Rhyme } & Test 3 & Folha & 1 & Filha \\
\hline & & Bolha & 1 & Pilha \\
\hline & Test 4 & Maré & 1 & Sopé \\
\hline Alliteration & Training 1 & Face & 1 & Faca \\
\hline $\begin{array}{l}\text { Syllabic and } \\
\text { Phonemic } \\
\text { Segmentation }\end{array}$ & Instructions & $\begin{array}{l}\text { "... o robô repetindo a } \\
\text { palavra..." }\end{array}$ & 2 & $\begin{array}{l}\text { "... o robô, a sua tarefa é } \\
\text { de repetir a palavra..." }\end{array}$ \\
\hline $\begin{array}{l}\text { Phonemic } \\
\text { Segmentation }\end{array}$ & Instruction & $\begin{array}{l}\text { "..., mas agora falando as } \\
\text { partes menores..., falando } \\
\text { cada som separadamente." }\end{array}$ & 2 & $\begin{array}{l}\text { "..., mas agora vai falar } \\
\text { as partes menores..., isto } \\
\text { é, cada som } \\
\text { separadamente." }\end{array}$ \\
\hline \multirow{2}{*}{$\begin{array}{l}\text { Syllabic and } \\
\text { Phonemic } \\
\text { Manipulation }\end{array}$} & Description & $\begin{array}{l}\text { "...sílabas de palavras } \\
\text { dizendo qual a palavra..." }\end{array}$ & 2 & $\begin{array}{l}\text { "...sílabas de palavras e } \\
\text { dizer qual é a palavra..." }\end{array}$ \\
\hline & Instruction & $\begin{array}{l}\text { "Você vai dizer } \\
\text { como fica..." }\end{array}$ & 2 & $\begin{array}{l}\text { "A sua tarefa é dizer } \\
\text { como fica..." }\end{array}$ \\
\hline $\begin{array}{l}\text { Syllabic } \\
\text { Manipulation }\end{array}$ & Training 1 & Macarrão & 1 & Camarão \\
\hline $\begin{array}{l}\text { Phonemic } \\
\text { Manipulation }\end{array}$ & Test 3 & Louça & 1 & Couve \\
\hline \multirow{2}{*}{$\begin{array}{l}\text { Syllabic and } \\
\text { Phonemic } \\
\text { Transposition }\end{array}$} & Description & $\begin{array}{l}\text { "... dizendo qual a } \\
\text { palavra formada." }\end{array}$ & 2 & $\begin{array}{l}\text { "... e dizer qual é a } \\
\text { palavra formada." }\end{array}$ \\
\hline & Instructions & $\begin{array}{l}\text { "Você vai falar uma } \\
\text { palavra..." }\end{array}$ & 2 & $\begin{array}{l}\text { "A sua tarefa é falar uma } \\
\text { palavra..." }\end{array}$ \\
\hline $\begin{array}{l}\text { Syllabic } \\
\text { Transposition }\end{array}$ & & Partes & 1 & Sílaba \\
\hline
\end{tabular}

Note. Source: Data from the validation questionnaire carried out by judges and experts.

\section{Discussion}

This study aimed to adapt a Brazilian instrument to the Mozambican context. One of the criteria to be considered for choosing an instrument to be adapted is that it has basic requirements, such as evidence of reliability and validity, and provides scientifically robust results in its studies. These aspects were taken into account. It was found that the PATOP is an instrument that has been used in research with the Brazilian population for the past 14 years, with studies of validity and precision using diversified techniques (Dias et al., 2013). 
Regarding adaptation itself, research suggests that this process can lead to dubious results if done inappropriately from a linguistic point of view concerning the common expressions of a given context. Nevertheless, some studies have shown the importance of semantic adaptation during the development or adaptation of instruments. However, the methodology used in them was not through natives, as it was used here. For example, Freitas et al. (2001), in a study of translation and adaptation, observed that even after the conceptual equivalence and the layout of the original instrument were preserved, the most significant difficulties in translation were related to semantic equivalence, in relation to colloquial forms and idiomatic expressions of Portuguese translated from the original instrument. However, at the end of the process, the problems were solved by consensus among the authors, many of them prioritizing adaptation to the Brazilian culture to the detriment of the experts' semantic equivalence. In another study, King and Bhugra (1989), evaluating underdeveloped and non-Western populations in India and Pakistan, used an instrument translated by experts. However, in analyzing the data, they found that there were consistent patterns of answers in five items that, according to them, could have been due to socio-cultural problems and interpretations, which led the authors to use expressions and concepts that had adequate meaning for the population because of linguistic, social and religious influences.

A significant step is related to expert validity and has been presented in many studies of translation and cultural adaptation of instruments. For example, in a Portuguese study, Ferreira and Pinto (2008) aimed to develop and validate an instrument for measuring the quality of life for patients in palliative care. So, through the comprehension and content validation test, they identified that the patients had doubts and hesitations regarding the number of answers they could score in a given question. The authors later considered and helped improve the quality of the Portuguese version of the instrument. In another study underway, in which the instrument to be applied was developed and did not have semantic validation, Bausewein et al. (2005) questioned whether the German version wording was clear and understandable. However, after the interviews with the participants, the results showed that $7 \%$ liked it a lot, $59 \%$ liked it, $29 \%$ were undecided, and $5 \%$ did not like the scale very much. It is important to remember that all the studies presented previously considered that the versions of the scale produced had good levels of reliability and other accepted indicators for their use. Thus, the recognition of the quality of the instrument becomes a fundamental aspect for the legitimacy and credibility of the research results (Medeiros et al., 2015).

Concerning the $\mathrm{CVI}$, there is a discussion among researchers about its value, requiring in some cases an agreement of at least $80 \%$ among the judges to serve as a criterion for accepting the instrument (Pasquali, 2010); and in others, agreement greater than or equal to 90\% (Wynd et al., 2003). However, for this study, the total CVI of the entire instrument related to agreement by the judges was 0.96 (96\%), which was also found in the study by 
Pieri et al. (2017). Thus, in both the first and second approaches to the value of CVI, the adapted PATOP presented an excellent content validity index that ensures that the instrument can be applied to the Mozambican population. Even so, these findings can be discussed, and some inferences can be made about it, since the CVI value was so close to 1 , that is, $100 \%$ agreement.

The first explanation can be given because the instrument underwent semantic adjustment by Mozambican natives residing in the country of origin of the instrument. They knew many Brazilian expressions, and this probably facilitated them to make some adjustments. The second may be due to the number of judges, since, in the literature, studies suggest that in those in which a minimum of five evaluators participate, the rate has been at least 90\% agreement (Lynn, 1986). The third and last might be because the cultural adaptation process of the instrument involved two countries or contexts that speak the same language, which theoretically would not require many adjustments compared to a process of translation and adaptation of an instrument, whose language was different between the two contexts, or probably if it were made from a variant of Portuguese that would not share the same varieties. This is because, according to Petter (2008), the basic vocabulary, made up mostly of terms of Portuguese origin, is shared by the Angolan, Brazilian, and Mozambican varieties of Portuguese. Still, according to the same author, this vocabulary has some local synonyms. Thus, it expresses an exclusive use not shared with the European Portuguese. On the other hand, it also presents, with relative autonomy, the use of the linguistic creation processes of European Portuguese.

At the same time, the use of natives was of great relevance because it is one of the fundamental methodological phases in studies of cultural adaptation of instruments (Hambleton \& Zenisky, 2010). Specifically in this study, the use of natives residing in the country of origin of the instrument was intended to facilitate the analysis and judgment of the instrument in phase 2 , since the judges would probably have more difficulties understanding many vernaculars used exclusively in Brazilian Portuguese if the instrument was not adapted previously or adapted by natives who never interacted with Portuguese and Brazilian culture. All these aspects mentioned above may have made the adaptation process more viable and less demanding, making the experts' judgment clearer and more objective, which was demonstrated in part by the few adaptations made in the PATOP and, consequently, may have received contribution from the high value of the CVI.

Regarding the CVI values of each section, it was found that the lowest score (0.75) was in the "contextualization" criterion of the "test data" section. In this particular case, it was not problems of contextualization or the number of adaptations and suggestions from experts that influenced this score. This was probably due to the number of items (1) evaluated in this section. The first judge scored the item as unclear, which consequently influenced the calcu- 
lation and this result. On the other hand, the section "structure and presentation of test" was the only one with $100 \%$ agreement among the judges. This fact may be because, as far as possible, the presentation of the adapted instrument may appear the same or very similar in all language versions. For example, O'Connor and Malak (2000) state that research suggests that, when presenting translated versions of instruments, the items must remain in the same pattern, order and page location in all versions. Thus, it may be that due to this care by the judges, this item of the adapted instrument had 100\% agreement.

In conclusion, it was found that, although the PATOP was developed in Portuguese (the same official language also in Mozambique), there was a need to adjust the test items to vernaculars of Portuguese spoken in Mozambique. The entire process was carried out in a careful, systematic and satisfactory manner, respecting the socio-cultural values of the two contexts, thus, fulfilling the proposed objectives. There was no elimination of any subtest of the original version, although minor adjustments were made due to differences in the languages of the two contexts.

However, although the adapted PATOP has presented excellent evidence of content validity, further studies of validity and precision and normative data should be performed in future studies to guarantee the quality of the instrument for use in the clinic and in the scientific research. In addition to this fact, some limitations of the study need to be considered. Firstly, this validation stage is considered subjective because it involves expert opinions, causing other evidence of validity and precision to be carried out in future studies. Secondly, there was no interaction among the judges' committee members to reach at a consensual position regarding the adaptations. Thirdly, since there is no control about the adapted components or phonological composition of the words, these fundamental aspects need to be controlled in the following studies. The fourth and last one is related to the little existing literature for cultural adaptation studies, in which the context of the origin of the instrument and the context of destination speak the same language. However, the literature points out the importance and need of these studies, especially with the immigrant population living in a specific context.

Despite the limitations, it is expected that the entire adaptation process will be an initial and fundamental step whose ultimate goal goes beyond making the instrument available to the Mozambican reality. This study is highly relevant for the education sector, mainly for evaluating, stimulating, and intervening in skills considered fundamental for academic performance. It is expected that, with the existence of the instrument, there will be a reflection and a profound debate on all fronts involved in the sector about the importance of these skills. On the other hand, with the dissemination of this knowledge, it is expected that playful and curricular activities will gradually be introduced, contemplating PA in early childhood services and mainly in daycare centers and kindergartens, in addition to further studies in the field being conducted, showing the importance of skills to children before they start the formal education. 


\section{References}

Bausewein, C., Fegg, M., Radbruch, L., Nauck, F., Von Mackensen, S., Borasio, G. D., \& Higginson, I. J. (2005). Validation and clinical application of the German version of the Palliative Care Outcome Scale. Journal of Pain and Symptom Management, 30(1), 51-62. https://doi.org/10.1016/j. jpainsymman.2005.01.017

Capovilla, A. G. S., \& Capovilla, F. C. (1998). Prova de consciência fonológica: Desenvolvimento de dez habilidades da pré-escola à segunda série. Temas Sobre Desenvolvimento, 7(37), 14-20.

Capovilla, A. G. S., Dias, N. M., \& Montiel, J. M. (2007). Desenvolvimento dos componentes da consciência fonológica no ensino fundamental e correlação com nota escolar. Psico-USF, 12(1), 5564. https://doi.org/10.1590/s1413-82712007000100007

Ciesielski, E. J. M., \& Creaghead, N. A. (2020). The effectiveness of professional development on the phonological awareness outcomes of preschool children: A systematic review. Literacy Research and Instruction, 59(2), 121-147. https://doi.org/https://doi.org/10.1080/19388071.2019.1710785

Coluci, M. Z. O., Alexandre, N. M. C., \& Milani, D. (2015). Construção de instrumentos de medida na área da saúde. Ciência e Saúde Coletiva, 20(3), 925-936. https://doi.org/ 10.1590/1413-81232015203.04332013

Diamanti, V., Mouzaki, A., Ralli, A., \& Antoniou, F. (2017). Preschool phonological and morphological awareness as longitudinal predictors of early reading and spelling development in Greek. Frontiers in Psychology, 8, 1-12. https://doi.org/10.3389/fpsyg.2017.02039

Dias, N. M., Duarte, C. P., Seabra, A. G., \& Macedo, E. C. (2013). Evidências de validade e fidedignidade da Prova de Consciência Fonológica por produção Oral. In A. G. Seabra \& N. M. Dias (Eds.), Avaliação Neuropsicológica Cognitiva: Linguagem oral (2nd ed., pp. 110-116). Memnon.

Dias, N. M., Trevisan, B. T., \& Seabra, A. G. (2013). Dados normativos da Prova de Consciência Fonológica por produção Oral. In A. G. Seabra \& N. M. Dias (Eds.), Avaliação Neuropsicológica Cognitiva: Linguagem oral (2nd ed., pp. 109-115). Memnon.

Fälth, L., Gustafson, S., \& Svensson, I. (2017). Phonological awareness training with articulation promotes early reading development. Education (Chula Vista, CA), 137(3), 261-276.

Ferreira, P., \& Pinto, A. (2008). Medir qualidade de vida em cuidados paliativos. Acta Médica Portuguesa, 21(2), 111-124. https://www.actamedicaportuguesa.com/revista/index.php/amp/article/ view/777/454

Fonseca, R. P., Casarin, F. S., De Oliveira, C. R., Gindri, G., Ishigaki, E. C. S. S., Ortiz, K. Z., Parente, M. A. D. M. P., \& Scherer, L. C. (2011). Adaptação de instrumentos neuropsicológicos verbais: Um fluxograma de procedimentos para além da tradução. Interação em Psicologia, 15, 59-69. https://doi.org/10.5380/psi.v15io.25374

Francisco, A. (2015). Estudo exploratório da situação da educação nos países participantes no PCSS-Lusófonos - Relatório de Moçambique (No. 2). 1-138.

Freitas, S., Lopes, C. S., Coutinho, W., \& Appolinario, J. C. (2001). Tradução e adaptação para o português da Escala de Compulsão Alimentar Periódica. Revista Brasileira de Psiquiatria, 23(4), 215220. https://doi.org/10.1590/S1516-44462001000400008

Fundação Aga Khan. (2011). Uso efectivo do tempo nas escolas de Cabo Delgado. Aga Khan. 
Germano, G. D., Pinheiro, F. H., \& Capellini, S. A. (2013). Desempenho de escolares com dislexia: Programas de intervenção metalinguístico e de leitura. Psicologia Argumento, 31(72), 11-22. https://repositorio.unesp.br/bitstream/handle/11449/114896/ISSN01037013-2013-31-72-1122.pdf? sequence $=1 \&$ isAllowed $=y$

Goswami, U. C., \& Bryant, P. E. (1990). Phonological skills and learning to read. Psychology Press Ltd.

Grant, J. S., \& Davis, L. L. (1997). Selection and use of content experts for instrument development. Research in Nursing \& Health, 20(3), 269-274. https://doi.org/10.1002/(SICl) 1098-240X(199706)20:3<269::AID-NUR9>3.0.CO;2-G

Guillemin, F. (1995). Cross-cultural adaptation and validation of health status measures. Scandinavian Journal of Rheumatology, 24(2), 61-63. https://doi.org/10.3109/03009749509099285

Hambleton, R. K. (2005). Issues, designs, and technical guidelines for adapting tests into multiple languages and cultures. In R. K. Hambleton, P. F. Merenda, \& C. D. Spielberger (Eds.), Adapting Educational and Psychological Tests for Cross-Cultural Assessment (pp. 3-38). Lawrence Erlbaum Associates.

Hambleton, R. K., \& Zenisky, A. L. (2010). Translating and Adapting Tests for Cross-Cultural Assessments. In D. Matsumoto \& F. J. R. van de Vijver (Eds.), Cross-Cultural Research Methods in Psychology (pp. 46-70). Cambridge University Press. https://doi.org/10.1017/ CBO9780511779381.004

King, M. B., \& Bhugra, D. (1989). Eating disorders: Lessons from a cross-cultural study. Psychological Medicine, 19(4), 955-958. https://doi.org/10.1017/S0033291700005675

Kjeldsen, A. C., Educ, L., Saarento-Zaprudin, S. K., \& Niemi, P. O. (2019). Kindergarten training in phonological awareness: Fluency and comprehension gains are greatest for readers at risk in grades 1 through 9. Journal of Learning Disabilities, 52(4), 366-382. https://doi. org/10.1177/0022219419847154

Lynn, M. R. (1986). Determination and quantification of content validity. Nursing Research, 35(6), 382-386. https://doi.org/10.1097/00006199-198611000-00017

Medeiros, R. K. da S., Júnior, M. A. F., Pinto, D. P. D. S. R., Vitor, A. F., Santos, V. E. P., \& Barichello, E. (2015). Modelo de validação de conteúdo de Pasquali nas pesquisas em Enfermagem. Revista de Enfermagem Referência, 4(4), 127-135. https://doi.org/10.12707/RIV14009

Morais, J. G. O. de. (2019). Geopolítica e história econômica das relações Brasil-Moçambique: A longa duração e a inflexão no governo Lula [Unpublished Master's Dissertation]. Universidade de São Paulo. https://doi.org/10.11606/D.31.2020.tde-16012020-124421

Nhampossa, C. D. J. (2018). Projecto "Turma Mais": Proposta de combate ao insucesso escolar na Matemática no Ensino Básico Moçambicano. UDZIWI, Revista de Educação da Universidade Pedagógica, 30, 42-59. http://www.revista.up.ac.mz/index.php/UDZIWI/article/view/324/315\#

O'Connor, K. M., \& Malak, B. (2000). Translation and cultural adaptation of the TIMSS instruments. In M. O. Martin, K. D. Gregory, \& S. E. Stemler (Eds.), TIMSS 1999 technical report (pp. 89-100). Chestnut Hill.

Pape-Neumann, J., Ermingen-Marbach, M. Van, Grande, M., \& Willmes, K. (2015). The role of phonological awareness in treatments of dyslexic primary school children. Acta Neurobiologiae Ex- 
perimentals, 75, 80-106. https://juser.fz-juelich.de/record/203333/files/Pape-Neumann_ etal_Acta\%20Neurobiol\%20Exp.pdf

Pasquali, L. (2003). Psicometria: Teoria dos testes na psicologia e na educação (5 ed.). Vozes.

Pasquali, L. (2010). Instrumentação psicológica: Fundamentos e práticas. Artmed.

Pasquali, L. (2013). Psicometria: Teoria dos testes na psicologia e na educação (5 ed.). Vozes.

Pazeto, T. de C. B., Dias, N. M., Gomes, C. M. A., \& Seabra, A. G. (2019). Prediction of arithmetic competence: Role of cognitive abilities, socioeconomic variables and the perception of the teacher in Early Childhood Education. Estudos de Psicologia, 24(3), 225-236. https://doi. org/10.22491/1678-4669.20190024

Petter, M. (2008). O léxico compartilhado pelo português angolano, brasileiro e moçambicano. VEREDAS (Revista da Associação Internacional de Lusitanistas), 9, 61-81. https://revistaveredas.org/ index.php/ver/article/view/15/15

Petter, M. M. T. (2009). Aspectos morfossintáticos comuns ao português angolano, brasileiro e moçambicano. PAPIA - Revista Brasileira de Estudos do Contato Linguístico, 19, 201-220. http://revistas.fflch.usp.br/papia/article/view/2016

Pieri, R. D. V., Pires, P., Filgueiras, A., \& Oliva, Â. D. (2017). Adaptação Transcultural e Validação de Conteúdo do Questionário de Coesão no Esporte Infantil para o Português do Brasil. Revista Brasileira de Psicologia do Esporte, 6(2), 14-25. https://doi.org/10.31501/rbpe.v6i2.7088

Pinto, G., Bigozzi, L., Tarchi, C., Vezzani, C., \& Gamannossi, B. A. (2016). Predicting reading, spelling, and mathematical skills: A longitudinal study from kindergarten through first grade. Psychological Reports, 118(2), 413-440. https://doi.org/10.1177/0033294116633357

Santos, A. A. A. dos, Ferraz, A. S., Lima, T. H. de, Cunha, N. de B., Suehiro, A. C. B., Oliveira, K. L. de, Anache, A. A., \& Silva, I. R. da. (2017). Habilidades linguísticas: A relação entre a consciência fonológica e a escrita. Estudos e Pesquisas em Psicologia, 17(2), 575-594. https://doi.org/10.12957/ epp.2017.37132

Seabra, A. G., \& Capovilla, F. C. (2011). Problemas de leitura e escrita: Como identificar, prevenir e remediar numa abordagem fônica ( 6 ed.). Memnon.

Seabra, A. G, \& Capovilla, F. C. (2012). Prova de Consciência Fonológica por Produção Oral Linguagem oral. In A. G Seabra \& N. M. Dias (Eds.), Avaliação Neuropsicológica Cognitiva. Memnon.

Shanahan, T., \& Lonigan, C. J. (2010). The national early literacy panel: A summary of the process and the report. Educational Researcher, 39(4), 279-285. https://doi.org/10.3102/ $0013189 \times 10369172$

Snowling, M. J., \& Melby-Lervåg, M. (2016). Oral language deficits in familial dyslexia: A meta-analysis and review. Psychological Bulletin, 142(5), 498-545. https://doi.org/10.1037/buloooo037

Song, S., Georgiou, G. K., Su, M., \& Hua, S. (2015). How well do phonological awareness and rapid automatized naming correlate with Chinese reading accuracy and fluency? A meta-analysis. Scientific Studies of Reading, 20(2), 99-123. https://doi.org/10.1080/10888438.2015.1088543

Timbane, A. A. (2016). O ensino da língua portuguesa em Moçambique e a problemática da formação de professores primários. Revista do Difere, 4(7), 1-21. https://www.researchgate.net/ 
publication/305935875_O_ENSINO_DA_LINGUA_PORTUGUESA_EM_MOCAMBIQUE_E_A_ PROBLEMATICA_DA_FORMACAO_DE_PROFESSORES_PRIMARIOS

TPC Moçambique. (2017). Será que as nossas crianças estão a aprender? Relatório anual sobre a aprendizagem em Moçambique (fase piloto, Nampula, 2016) (A. Ali (ed.)). Elográfico.

UNESCO. (2007). Relatório de Monitoramento Global de Educação Para Todos - EPT 2007 - Bases Sólidas: Educação e Cuidados na Primeira Infância. UNESCO.

UNESCO. (2012). Expanding equitable early childhood care and education is an urgent need. Education for All Global (3rd ed.). UNESCO.

Vibulpatanavong, K., \& Evans, D. (2019). Phonological awareness and reading in Thai children. Reading and Writing, 32, 467-491. https://doi.org/10.1007/s11145-018-9867-0

Wynd, C. A., Schmidt, B., \& Schaefer, M. A. (2003). Two quantitative approaches for estimating content validity. Western Journal of Nursing Research, 25(5), 508-518. https://doi. org/10.1177/0193945903252998

Editorial board

Editor-in-chief

Cristiane Silvestre de Paula

\section{Associated editors}

Alessandra Gotuzo Seabra

Ana Alexandra Caldas Osório

Luiz Renato Rodrigues Carreiro

Maria Cristina Triguero

Veloz Teixeira

\section{Section editors}

"Psychological Evaluation"

Alexandre Luiz de Oliveira Serpa

André Luiz de Carvalho

Braule Pinto

Luiz Renato Rodrigues Carreiro

Vera Lúcia Esteves Mateus

"Psychology and Education"

Alessandra Gotuzo Seabra

Carlo Schmidt

Regina Basso Zanon

\section{"Social Psychology and \\ Population's Health" \\ Enzo Banti Bissoli \\ Marina Xavier Carpena}

\section{"Clinical Psychology"}

Carolina Andrea Ziebold Jorquera

Julia Garcia Durand

Natalia Becker

\section{"Human Development"}

Maria Cristina Triguero

Veloz Teixeira

Rosane Lowenthal

\section{Technical support}

Maria Fernanda Liuti

Bento da Silva

Camila Fragoso Ribeiro
Editorial production

Publishing coordination

Ana Claudia de Mauro

Editorial interns

Júlia Lins Reis

Pietro Menezes

Élcio Carvalho

\section{Language editor}

Daniel Leão

Layout designer

Acqua 